\title{
Modifikasi Jembatan Buol Sulawesi Tengah Menggunakan Jembatan Busur Menerus Rangka Baja
}

\author{
R. Dary Wira Mahadika dan Endah Wahyuni \\ Departemen Teknik Sipil, Fakultas Teknik Sipil dan Perencanaan, Institut Teknologi Sepuluh Nopember (ITS) \\ e-mail: endah@ce.its.ac.id
}

\begin{abstract}
Abstrak-Jembatan Buol termasuk jembatan kelas nasional yang menghubungkan jalan lintas provinsi antara provinsi Sulawesi Tengah dan Gorontalo. Jembatan ini terletak diatas sungai Buol Kabupaten Buol Sulawesi Tengah dan menggunakan konstruksi rangka batang baja sederhana sebagai struktur utamanya. Jembatan Buol memiliki estetika yang kurang baik. Hal ini yang melatarbelakangi pembangunan Jembatan Buol yang baru, sebagai solusi dalam pembangunan jembatan yang memiliki estetika yang baik, kuat dan dapat menjadi landmark bagi kabupaten Buol. Tugas akhir ini memodifikasi Jembatan Buol menjadi Jembatan Busur Menerus Rangka Baja. Jembatan didesain dengan bentang pelengkung menerus rangka baja sepanjang $223.5 \mathrm{~m}$ dengan lebar 9 meter dan tinggi 20.5 meter. Tugas akhir ini berpedoman pada beberapa standar peraturan yang ada. Untuk pembebanan jembatan beserta kombinasi pembebanan mengacu pada SNI 1725:2016, perencanaan struktur baja disesuaikan pada RSNI T-03-2005. Untuk desain pelat kendaraan menggunakan SNI 2847-2013, serta untuk perencanaan ketahanan gempa menggunakan SNI 2833:2008. Dengan menggunakan progam bantu SAP2000, kombinasi KUAT 1 (SNI-1725-2016) menghasilkan output gaya yang lebih besar daripada kombinasi lainnya sehingga kombinasi tersebut digunakan untuk menentukan profil rangka jembatan. Analisis perletakan menggunakan progam bantu SAP2000 dengan kombinasi beban yang menentukan dalam perencanaan POT Bearing adalah kombinasi EKSTREM I (SNI-1725-2016) dan KUAT 1 (SNI-1725-2016). Hasil dari analisa dengan progam bantu SAP2000 profil utama yang terbesar pada jembatan busur menggunakan BOX 650 x 650 x 36. Dalam merencanakan bangunan bawah jembatan, dilakukan analisis menggunakan program bantu spcolumn untuk mendapatkan jumlah tulangan longitudinal pada abutment dan pilar jembatan, serta untuk tiang pancang jembatan dilakukan kontrol berdasarkan daya dukung tanah dan tipe material yang digunakan. Dari perencanaan tersebut, didapatkan dimensi abutmen 11.1 x 2.1 x 7.3 meter dan pilar $11.4 \times 2.1 \times 1.4$ meter serta kebutuhan tiang pancang untuk abutment sebanyak 21 buah dan pilar sebanyak 60 buah.
\end{abstract}

Kata Kunci-Abutmen, Jembatan Busur, Jembatan Busur Menerus, Pilar, POT Bearing.

\section{PENDAHULUAN}

$\mathrm{J}$ EMBATAN merupakan struktur yang dibuat untuk menyeberangi jurang atau rintangan seperti sungai, rel kereta api ataupun jalan raya. Dalam perencanaan jembatan, sebaiknya tidak hanya mempertimbangkan aspek struktural saja, tetapi juga perlu meninjau aspek estetika.

Pada kondisi saat ini, jembatan di sungai Buol kabupaten Buol Sulawesi Tengah merupakan jembatan dengan konstruksi rangka batang baja sederhana (lihat Gambar 1). Jembatan ini termasuk jembatan kelas nasional yang menghubungkan jalan lintas provinsi antara provinsi Sulawesi Tengah dan Gorontalo.
Jembatan Buol terletak di Kabupaten Buol Sulawesi Tengah yang termasuk dalam wilayah zona gempa 2 menurut [1] (lihat Gambar 2) Jembatan ini memiliki panjang bentang bersih yaitu 223.5 m dengan 4 segmen dan 3 pilar. Setiap segmennya memiliki panjang bentang sebesar 55.875 meter dan lebar 9 meter.

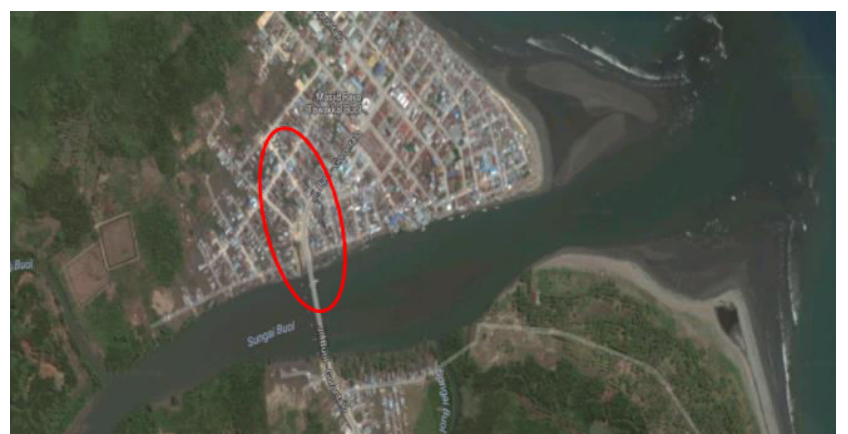

Gambar 1. Lokasi Jembatan Buol.

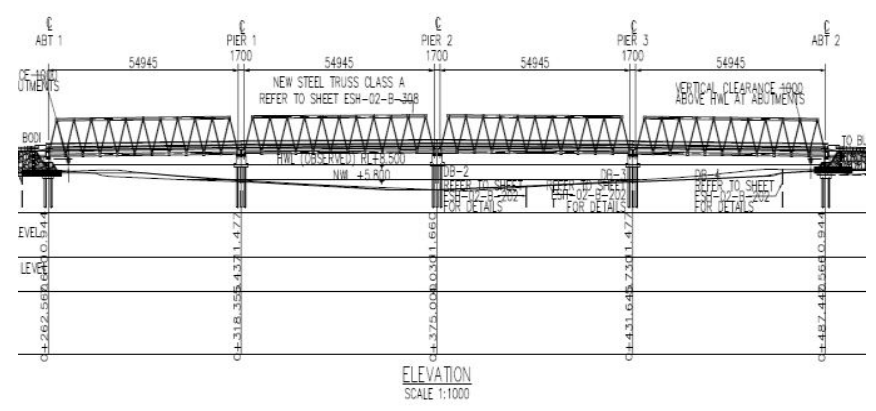

Gambar 2. Konstruksi Existing Jembatan Buol

Jembatan Buol memiliki estetika yang kurang baik karena jembatan ini terdiri dari 4 jembatan dengan bentuk rangka baja yang sama. Mengulang span yang sama berulang kali akan terlihat membosankan dan monoton [2]. Oleh karena itu, dengan kondisi jembatan Buol saat ini dibutuhkan jembatan baru selain kuat serta memiliki estetika yang baik.

Jembatan dengan tipe Continuous steel truss arch memiliki keunggulan dalam kekuatan dan estetika. Dalam hal kekuatan, Continuous steel truss arch lebih kaku serta membutuhkan expansion joint dan pilar yang lebih sedikit dibandingkan dengan model simple steel truss. Sedangkan dalam hal estetika, Continuous steel truss arch menggunakan satu bentuk melengkung menerus dan tidak mengulang bentuk yang sama. Selain itu model ini masih sedikit digunakan di Indonesia sehingga tidak terlihat membosankan dan menjadi landmark bagi Kabupaten Buol yang dapat meningkatkan perekonomian warga sekitar. 


\section{METODOLOGI}

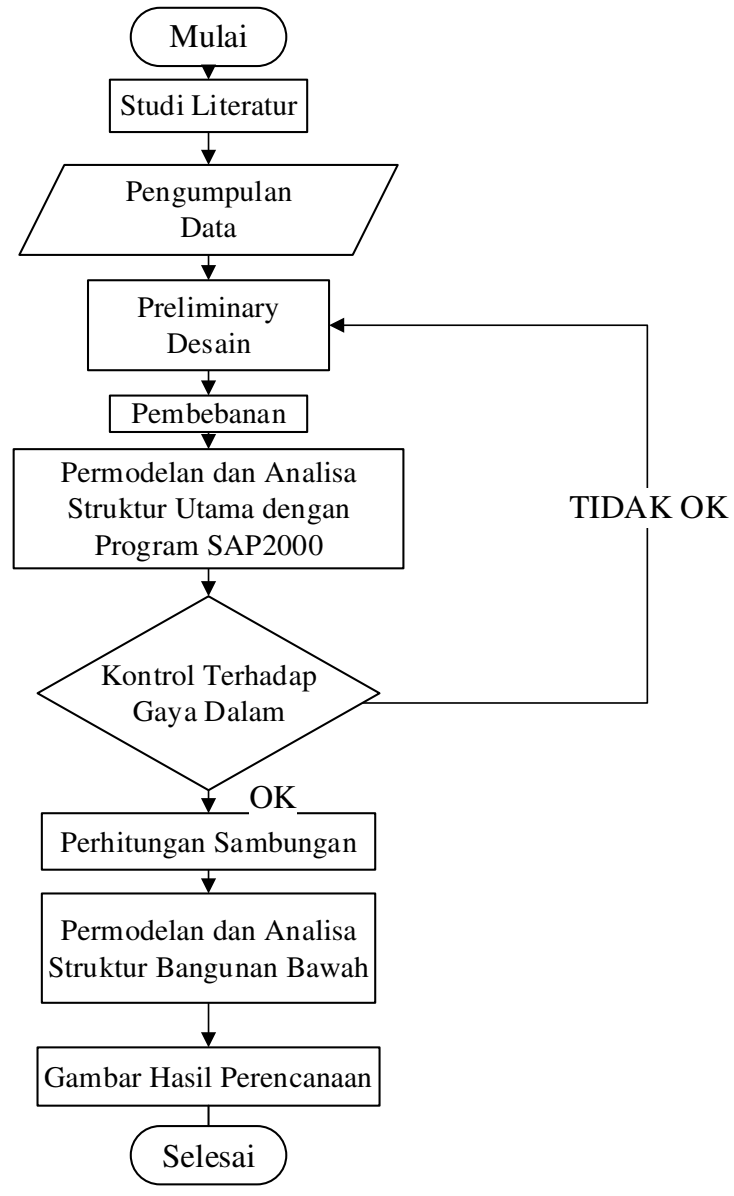

Gambar 3. Diagram Alir.

Adapun keterangan dari bagan metodologi di atas adalah sebagai berikut:

\section{A. Studi Literatur}

Melakukan studi literatur dengan berpedoman beberapa standar peraturan sebagai bahan pustaka dalam pengerjaan tugas akhir, antara lain:

a. Bridges Management System (BMS) 1992

b. SNI 1725:2016

c. SNI $2847: 2013$

d. RSNI T-03-2005

e. SNI 2833:2008

B. Pengumpulan Data

Data yang diperlukan antara lain :

- Bentang jembatan : 223.5 meter

- Data tanah : : Standar Penetrasi Test (SPT)

- Lokasi : Kabupaten Buol

- Ruas Jalan : Buol - Gorontalo

- Letak Jembatan : : $720 \mathrm{~m}$ dari pantai

- Zona wilayah gempa : 2 (SNI 2833:2008)

C. Preliminary Design

1. Penentuan mutu bahan yang digunakan:

- Mutu Beton Pelat (f'c) $=25 \mathrm{MPa}$.

- Mutu Beton Pilar (f'c) $=29 \mathrm{MPa}$.

- Mutu Beton Abutment (f'c) = $29 \mathrm{MPa}$.

- Mutu Baja Tulangan (fy) $=40 \mathrm{MPa}$

- Struktur utama (fy)

Profil Circullar Hollow : $: 317 \mathrm{MPa}$
(A500 Grade B)

Profil Box, Siku dan WF : $250 \mathrm{MPa}$ (A36)

- Mutu baut sambungan menggunakan ASTM A325 untuk sambungan baut antar profil;

- Mutu las yang digunakan adalah E70xx [3] Memperkirakan tebal pelat lantai kendaraan

Pelat lantai yang berfungsi sebagai jalan kendaraan pada jembatan harus mempunyai tebal minimum $t s$, dengan ketebalan $20 \mathrm{~cm}$ [4].

2. Menentukan Dimensi Busur

- Tinggi Busur

Syarat: $\frac{1}{6} \leq \frac{f}{L}$

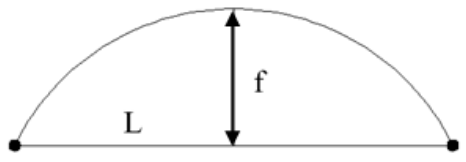

Gambar 4. Tinggi Busur.

- Tinggi Tampang Busur

Tinggi tampang busur rangka batang dengan batang tarik dapat menggunakan syarat sebagai berikut [5]:

Syarat: $\frac{1}{40} \leq \frac{t}{L} \leq \frac{1}{20}$

- Lebar Jembatan

Lebar jembatan dapat menggunakan syarat sebagai berikut [5]:

$$
\text { Syarat: } \frac{b}{L} \geq \frac{1}{20}
$$

3. Pembebanan

Pembebanan yang bekerja pada struktur jembatan terdiri dari beban mati (berat sendiri dan beban mati tambahan), beban hidup, beban angin dan beban gempa [6].

D. Permodelan dan Analisa Struktur Utama dengan Program SAP2000

Tugas Akhir ini memodelkan Jembatan Busur Menerus Buol dengan menggunakan progam bantu SAP2000. Pemodelan 2 Dimensi untuk mendapatkan garis pengaruh pada jembatan dan pemodelan 3 Dimensi untuk mendapatkan profil yang digunakan sesuai kombinasi pembebanan SNI 1725-2016 [6].

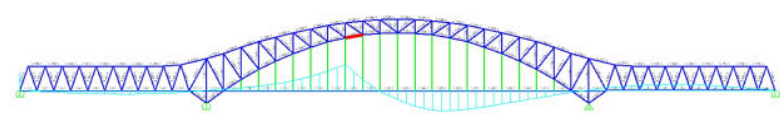

Gambar 5. Pemodelan 2 Dimensi Jembatan dengan SAP2000.

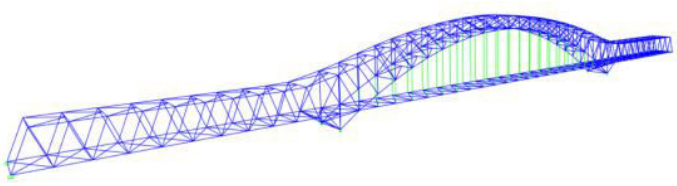

Gambar 6. Pemodelan 3 Dimensi Jembatan dengan SAP2000.

Profil struktur sekunder Jembatan Buol menggunakan produk dari 3 sumber yaitu JFE Steel Coorporation [7] untuk profil WF dengan mutu baja ASTM A36 (fu $=390$ 
Mpa dan fy $=250 \mathrm{Mpa}$ ), PT. Gunung Garuda [8] untuk profil siku dengan mutu baja ASTM A36 (fu $=390 \mathrm{Mpa}$ dan fy $=250 \mathrm{Mpa})$ dan Steel Tube Institute of North America [9] untuk profil Circullar hollow dengan mutu ASTM A500 GrB (fu $=400$ Mpa dan fy $=290$ Mpa). Dari hasil perhitungan struktur sekunder jembatan busur didapatkan:

- Gelagar memanjang WF 434 × 299 x 10 x 15

- Gelagar melintang WF 786 x 384 x 19.7 x 33.4

- Ikatan angin lantai kendaraan L 200 x 200 x 20

- Ikatan angin tepi atas O 8.625"

- Ikatan silang angin rangka O 7"

- Ikatan angin tepi bawah O 8.625"

Profil rangka utama menggunakan brosur Corus Tubes Structural \& Conveyance Business [10] yang memiliki mutu SN490 B (fy = 345 Mpa dan fu $=490 \mathrm{Mpa})$

Berikut merupakan rekap profil rangka utama jembatan:

- Batang tepi atas segmen 1 - 2 Box 550 x 550 x 32

- Batang tepi atas segmen $3 \& 5$ Box 350 x 350 x 19

- Batang tepi atas segmen $4 \& 6$ Box 400 x 400 x 22

- Batang tepi bawah segmen 1 \& 6 Box 350 x 350 x 19

- Batang tepi bawah segmen 2 Box 500 x 500 x 28

- Batang tepi bawah segmen 3 \& 4 Box 650 x 650 x 36

- Batang tepi bawah segmen 5 Box 450 x 450 x 25

- Batang vertikal segment $1 \& 3$ Box 350 x 350 x 19

- Batang vertikal segment 4 Box 450 x $450 \times 25$

- Batang vertikal segment 5 \& 6 Box 350 x 350 x 19

- Batang diagonal segmen 1 - 3 Box 350 x 350 x 19

- Batang diagonal segmen 4 \& 5 Box 400 x 400 x 22

- Batang diagonal segmen 6 Box 350 x 350 x 19

- $\quad$ Batang tarik Box $500 \times 500 \times 28$

- Kolom portal akhir Box 500 x 500 x 22

- Balok portal akhir Box 500 x 500 x 22

- Batang penggantung Full Locked Cables berdiameter $50 \mathrm{~mm}$ (fy $=734 \mathrm{Mpa}$ dan $\mathrm{fu}=1211.64$ Mpa)

Perletakaan yang digunakan mengguanakan POT Bearing dari perusahaan Freyssinet dengan tipe GG 30000, GG 20000, FX 30000 dan GL 4000 [11].

\section{E. Kontrol Gaya Dalam}

1. Kontrol Kapasitas Tarik

Batas kekuatan [3]

$\mathrm{N}_{\mathrm{u}} \leq \emptyset_{t} N_{n} \quad \emptyset_{t}=0.9$

Nilai $\mathrm{N}_{\mathrm{n}}$ diambil sebagai nilai terendah dari beberapa persamaan dibawah ini:

Kontrol leleh : $\mathrm{N}_{\mathrm{u}} \leq \emptyset_{t} f_{y} A_{g} \emptyset_{t}=0.75$

Kontrol putus : $\mathrm{N}_{\mathrm{u}} \leq \emptyset_{t} f_{u} A_{e} \emptyset_{t}=0.75$

Luas Penampang Efektif:

$\mathrm{A}_{\mathrm{e}}=\mathrm{Ax}\left(1-\frac{x}{L}\right)$

Dimana:

$\mathrm{N}_{\mathrm{u}}$ : Gaya Tarik aksial terfaktor (N)

$f_{y}$ : Tegangan leleh $(\mathrm{MPa})$

$f_{u} \quad$ : Tegangan tarik putus (MPa)

$\mathrm{A}_{\mathrm{g}}$ : Luas penampang bruto $\left(\mathrm{mm}^{2}\right)$

$\mathrm{A}_{\mathrm{e}}$ : Luas penampang efektif $\left(\mathrm{mm}^{2}\right)$

$\mathrm{x} \quad$ : eksentrisitas sambungan $(\mathrm{mm})$ (Tabel 1.)
Tabel 1.

Eksentrisitas Sambungan [12]

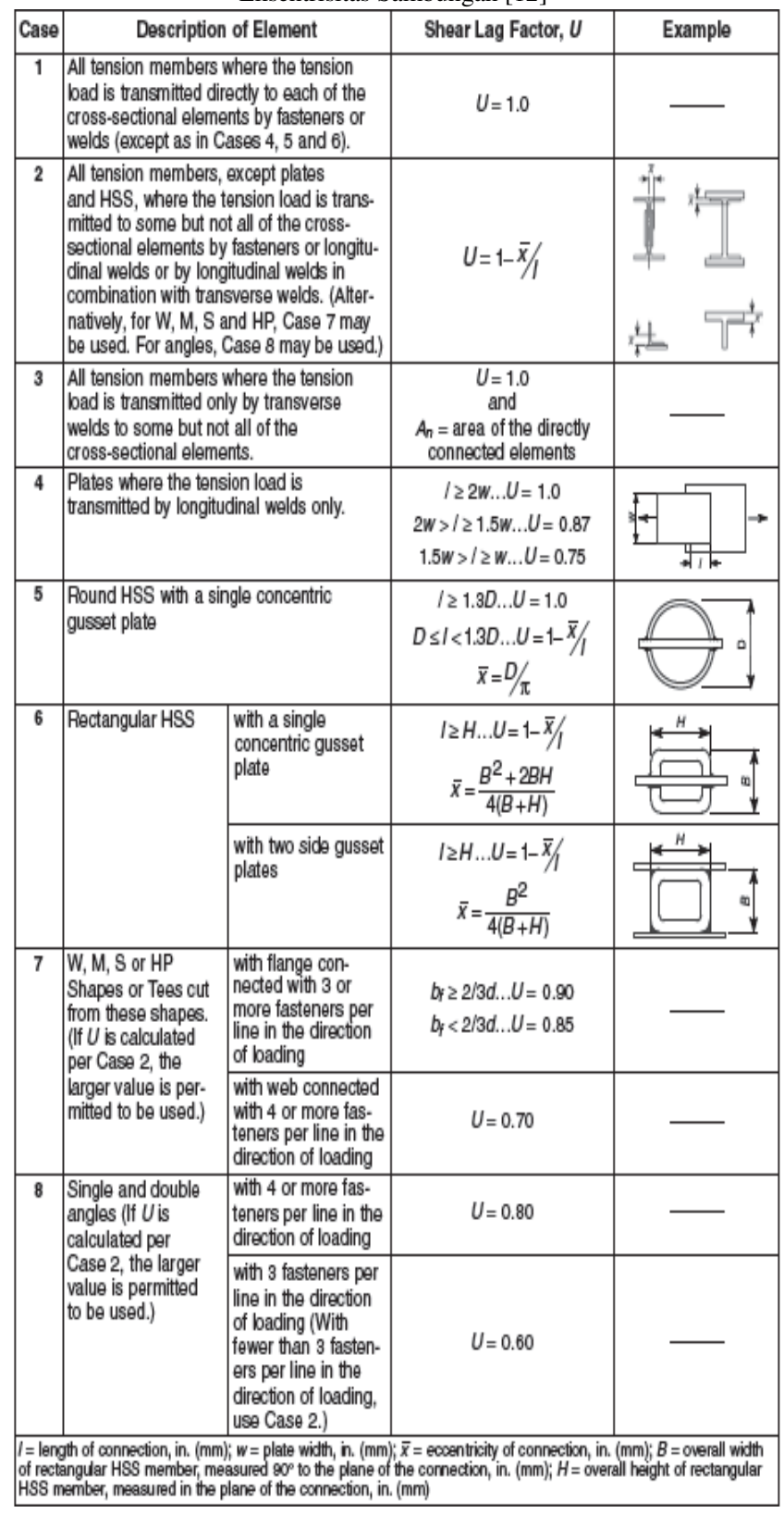

2. Kontrol Kapasitas Tekan

Batas kekuatan [3]

$N_{u} \leq \phi_{n} N_{n} \quad \phi_{n}=0.85$

Kekuatan tekan nominal

$N_{n}=\left(0.66^{\lambda_{c}{ }^{2}}\right) A g f y$ untuk $\lambda_{c} \leq 1,5$

$N_{n}=\frac{(0,88)}{\lambda_{c}{ }^{2}} A g f y \quad$ untuk $\lambda_{c} \geq 1,5$

$\lambda_{c}=\frac{L_{k}}{r \pi} \sqrt{\frac{f y}{E}}$

$\mathrm{Lk}=\mathrm{K}_{\mathrm{c} x} \mathrm{~L}$

Dimana:

$\mathrm{N}_{\mathrm{n}}$ : Kuat tekan nominal komponen (N)

$\mathrm{K}_{\mathrm{c}}$ : Faktor panjang tekuk untuk komponen struktur $\lambda_{c}$ : Kelangsingan Komponen Struktur Tekan [13] 

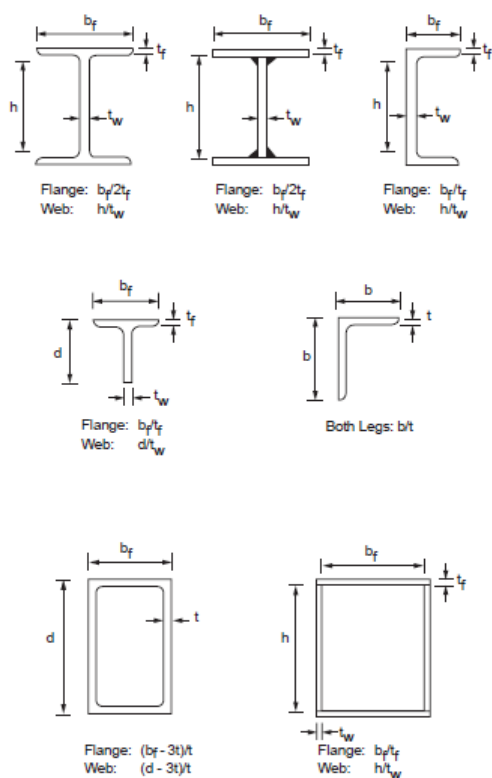

Gambar 7. Rasio Tebal dan Lebar Penampang untuk Kontrol Kelangsingan Penampang [13].

Tabel 2.

Hasil Kontrol Tekan

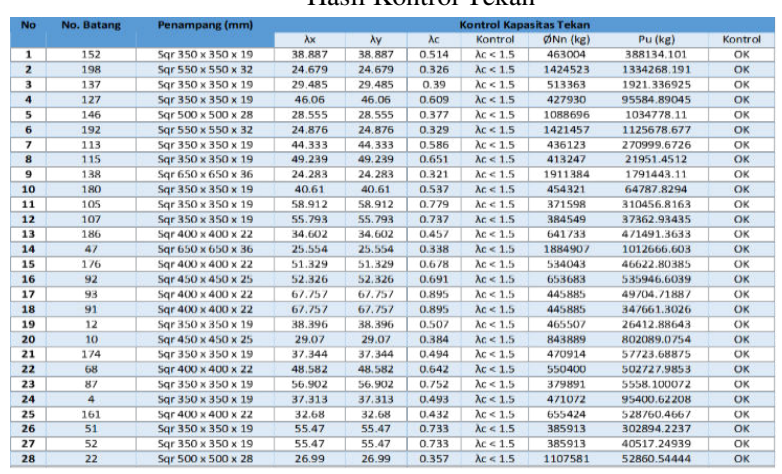

Tabel 3.

Hasil Kontrol Tarik

\begin{tabular}{|c|c|c|c|c|c|}
\hline No & No. Batang & Penampang (mm) & \multicolumn{3}{|c|}{ Kontrol Kapasitas Tarik } \\
\hline $\mathbf{1}$ & 152 & Sqr $350 \times 350 \times 19$ & 751410 & 199927.8925 & OK \\
\hline $\mathbf{2}$ & 198 & Sqr $550 \times 550 \times 32$ & 1977885 & 29147.81207 & OK \\
\hline $\mathbf{3}$ & 137 & Sqr $350 \times 350 \times 19$ & 751410 & 77691.52086 & OK \\
\hline $\mathbf{4}$ & 127 & Sqr $350 \times 350 \times 19$ & 751410 & 284881.574 & OK \\
\hline $\mathbf{5}$ & 146 & Sqr $500 \times 500 \times 28$ & 1577340 & 147716.4486 & OK \\
\hline $\mathbf{6}$ & 192 & Sqr $550 \times 550 \times 32$ & 1977885 & 113271.7846 & OK \\
\hline $\mathbf{7}$ & 113 & Sqr $350 \times 350 \times 19$ & 751410 & 23785.1635 & OK \\
\hline $\mathbf{8}$ & 115 & Sqr $350 \times 350 \times 19$ & 751410 & 345125.8094 & OK \\
\hline $\mathbf{9}$ & 138 & Sqr $650 \times 650 \times 36$ & 2642355 & 43260.43251 & OK \\
\hline $\mathbf{1 0}$ & 180 & Sqr $350 \times 350 \times 19$ & 751410 & 424765.6314 & OK \\
\hline $\mathbf{1 1}$ & 105 & Sqr $350 \times 350 \times 19$ & 751410 & 33989.9497 & OK \\
\hline $\mathbf{1 2}$ & 107 & Sqr $350 \times 350 \times 19$ & 751410 & 327373.4072 & OK \\
\hline $\mathbf{1 3}$ & 186 & Sqr $400 \times 400 \times 22$ & 993600 & 177062.9057 & OK \\
\hline $\mathbf{1 4}$ & 47 & Sqr $650 \times 650 \times 36$ & 2642355 & 8925.725904 & OK \\
\hline $\mathbf{1 5}$ & 176 & Sqr $400 \times 400 \times 22$ & 993600 & 902380.4837 & OK \\
\hline $\mathbf{1 6}$ & 92 & Sqr $450 \times 450 \times 25$ & 1229580 & 21454.26407 & OK \\
\hline $\mathbf{1 7}$ & 93 & Sqr $400 \times 400 \times 22$ & 993600 & 786995.4754 & OK \\
\hline $\mathbf{1 8}$ & 91 & Sqr $400 \times 400 \times 22$ & 993600 & 119154.6685 & OK \\
\hline $\mathbf{1 9}$ & 12 & Sqr $350 \times 350 \times 19$ & 751410 & 134146.2275 & OK \\
\hline $\mathbf{2 0}$ & 10 & Sqr $450 \times 450 \times 25$ & 1229580 & 46635.77555 & OK \\
\hline $\mathbf{2 1}$ & 174 & Sqr $350 \times 350 \times 19$ & 751410 & 667031.9631 & OK \\
\hline $\mathbf{2 2}$ & 68 & Sqr $400 \times 400 \times 22$ & 993600 & 6074.50165 & OK \\
\hline $\mathbf{2 3}$ & 87 & Sqr $350 \times 350 \times 19$ & 751410 & 598197.1589 & OK \\
\hline $\mathbf{2 4}$ & 4 & Sqr $350 \times 350 \times 19$ & 751410 & 512453.0049 & OK \\
\hline $\mathbf{2 5}$ & 161 & Sqr $400 \times 400 \times 22$ & 993600 & 109025.5576 & OK \\
\hline $\mathbf{2 6}$ & 51 & Sqr $350 \times 350 \times 19$ & 751410 & 27327.19115 & OK \\
\hline $\mathbf{2 7}$ & 52 & Sqr $350 \times 350 \times 19$ & 751410 & 356440.8799 & OK \\
\hline $\mathbf{2 8}$ & 22 & Sqr $500 \times 500 \times 28$ & 1577340 & 1244282.416 & OK \\
\hline & & & & & \\
\hline
\end{tabular}

\section{F. Perhitungan Sambungan}

Sambungan yang digunakan pada Tugas Akhir ini adalah sambungan baut tipe friksi [3] dan untuk contoh salah satu sambungan dapat dilihat sebagai berikut:

Kuat geser nominal

$(\mathrm{Vn})=1.13 \times \mu \times \mathrm{n}_{\mathrm{ei}} \times \mathrm{n}_{\mathrm{ti}} \times \mathrm{k}_{\mathrm{h}}$

Kuat rencana:

$\mathrm{V}_{\mathrm{d}}=\varnothing \mathrm{Vn}$

Dimana:

- $\mu$ : Koefisien geser

- $\quad \mathrm{n}_{\mathrm{ti}}$ : Gaya tarik minimum $(\mathrm{kN})$

- $\mathrm{n}_{\mathrm{ei}}:$ Jumlah permukaan antara efektif

- $\varnothing: 0.75$

- $\mathrm{K}_{\mathrm{h}}: 1,00$ untuk lubang standar

Sambungan Batang Tarik

$\mathrm{Vu}=1244282.416 \mathrm{~kg}$

Pelat Sambung $\mathrm{t}=40 \mathrm{~mm} \mathrm{~A} 36(\mathrm{fy}=250 \mathrm{MPa}, \mathrm{fu}=400$ $\mathrm{MPa})$

Spesifikasi profil square hollow 500 × 500 x 28 yang dibutuhkan pada perhitungan ini sebagai berikut:

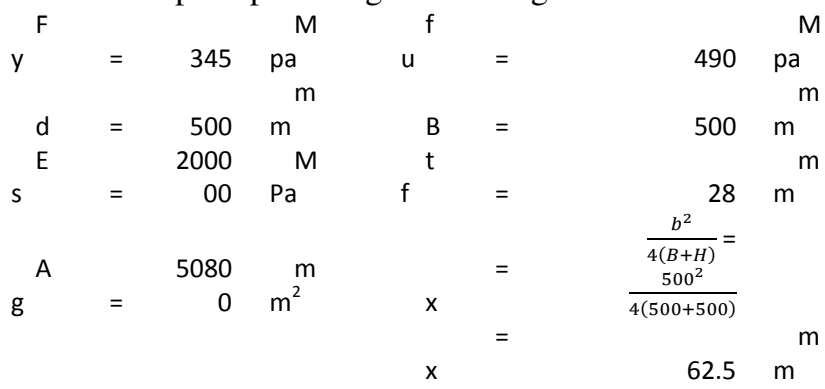

Baut Tipe A325

Diameter baut $(\mathrm{db}) \quad=24 \mathrm{~mm}$

Gaya tarik minimum $=21000 \mathrm{~kg}$

Jumlah bidang geser $=1$

$\mathrm{K}_{\mathrm{h}}$

$=1$ (Lubang standar)

$\mu \quad=0.35$ (Giling bersih)

Kuat Rencana Baut Tipe Gesek (Friction Type)

Kuat Geser $\left(\mathrm{V}_{\mathrm{sf}}\right)=1.13 \times \mu \times \mathrm{n}_{\mathrm{ei}} \times \mathrm{N}_{\mathrm{ti}} \times \mathrm{k}_{\mathrm{h}}$ $=1.13 \times 0.35 \times 1 \times 21000 \mathrm{~kg} \times 1$ $=8305.5 \mathrm{~kg}$

Jumlah Baut (n)

$\frac{V u}{V_{s f}}=\frac{1244282.416}{8305.5}=149=150$ buah

Penempatan baut

50 buah untuk sisi bawah, kiri dan kanan.

Jarak Pemasangan Baut

Syarat $: 2.5 \mathrm{~d}_{\mathrm{b}} \leq \mathrm{S} \leq 15 \mathrm{t}_{\mathrm{p}}$

$1.5 \mathrm{~d}_{\mathrm{b}} \leq \mathrm{S} 1 \leq\left(4 \mathrm{t}_{\mathrm{p}}+100\right)$

$1.25 \mathrm{~d}_{\mathrm{b}} \leq \mathrm{S} 2 \leq 12 \mathrm{t}_{\mathrm{p}}$

Maka:

Untuk jarak $\mathrm{S}: 2.5 \times 24 \leq \mathrm{S} \leq 15 \times 28$ $60 \mathrm{~mm} \leq \mathrm{S} \leq 420 \mathrm{~mm}$

Jarak S : $60 \mathrm{~mm}$

Untuk jarak S1 : $1.5 \times 24 \leq \mathrm{S} 1 \leq(4 \times 28+100)$ $36 \mathrm{~mm} \leq \mathrm{S} 1 \leq 212 \mathrm{~mm}$

Jarak S1 : $90 \mathrm{~mm}$

Untuk jarak S2 : $1.25 \times 24 \leq \mathrm{S} 2 \leq 12 \times 28$

Jarak S2 : $130 \mathrm{~mm}$ 


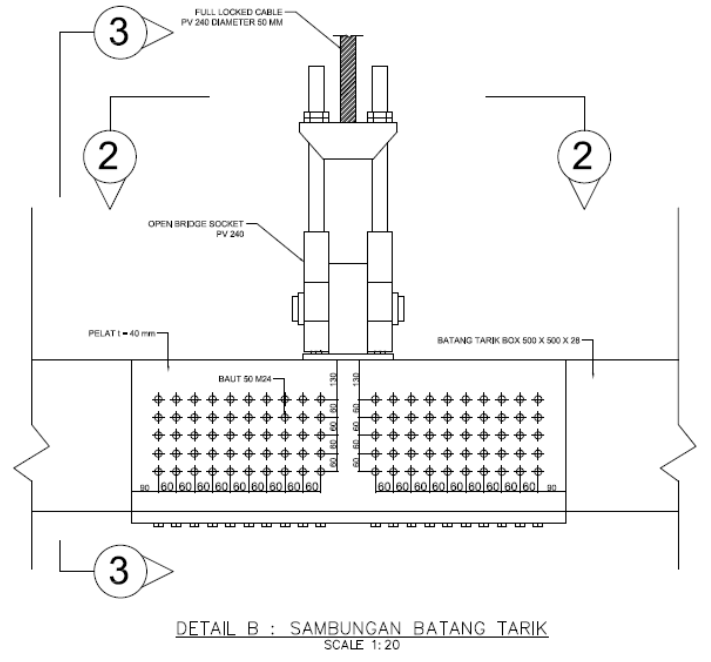

Gambar 8. Sambungan Batang Tarik

\section{G. Perencanaan Bangunan Bawah}

Berat sendiri dari abutment dan pilar jembatan ditambah tanah dibelakangnya dibagi menjadi beberapa segmen. Pembagian segmen tersebut dapat dilihat pada Gambar 9 dan Gambar 10.

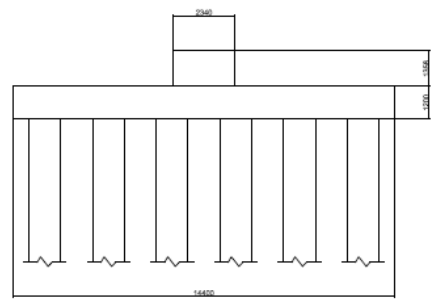

$\frac{\text { PIIAR P1 }}{\text { SCAAE } 1: 200}$
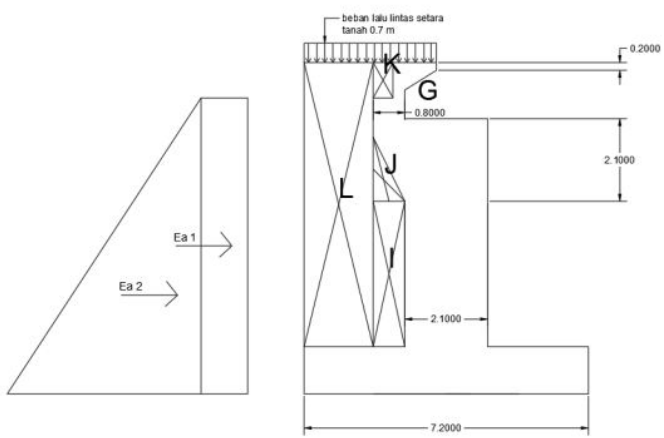

Gambar 9. Sketsa Pembagian Berat Sendiri pada Abutment Jembatan dan Tanah dibelakang Abutment.

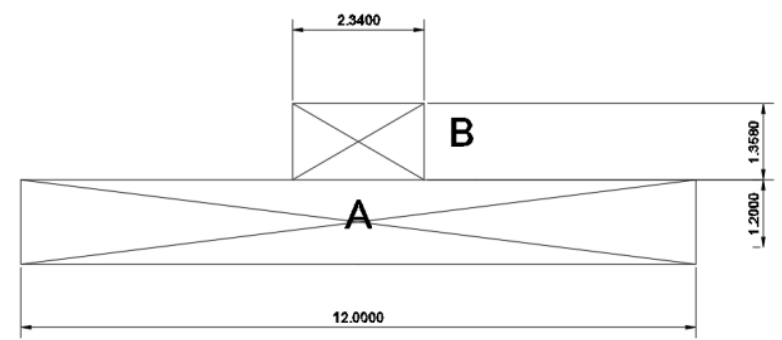

Gambar 10. Sketsa Pembagian Beban Sendiri pada Pilar

Pembagian segmen tersebut untuk mendapatkan berat total pilar dan abutment serta tanah dibelakang abutment. Kombinasi pembebanan pada struktur bangunan bawah Jembatan Busur Buol dapat dilihat pada Tabel 4. [6].

Tabel 4.

Kombinasi Pembebanan pada Jembatan Buol

\begin{tabular}{|c|c|c|c|c|c|}
\hline \multicolumn{7}{|c|}{ Kombinasi Pembebanan Pilar } \\
\hline Kombinasi & $\mathrm{P}(\mathrm{t})$ & $\mathrm{Mx}(\mathrm{tm})$ & $\mathrm{My}(\mathrm{tm})$ & $\mathrm{Hx}(\mathrm{t})$ & $\mathrm{Hy}(\mathrm{t})$ \\
\hline Kuat 1 & 5126.28 & 128.61 & 0.13 & 45.00 & 0.00 \\
\hline Kuat 3 & 3487.96 & 128.61 & 554.27 & 45.00 & 86.20 \\
\hline Kuat 5 & 3487.96 & 128.61 & 260.65 & 45.00 & 39.81 \\
\hline Ekstreme 1 & 3680.65 & 5365.84 & 1696.08 & 2075.33 & 890.22 \\
\hline Daya Layan 1 & 3089.83 & 71.45 & 221.06 & 25.00 & 33.65 \\
\hline \multicolumn{7}{|c|}{ Kombinasi Pembebanan Abutment } \\
\hline Kombinasi & $\mathrm{P}(\mathrm{t})$ & $\mathrm{Mx}(\mathrm{tm})$ & $\mathrm{My}(\mathrm{tm})$ & $\mathrm{Hx}(\mathrm{t})$ & $\mathrm{Hy}(\mathrm{t})$ \\
\hline Kuat 1 & 1816.43 & 549.11 & -0.48 & 324.16 & - \\
\hline Kuat 3 & 1296.39 & 549.11 & 1004.04 & 324.16 & 13.65 \\
\hline Kuat 5 & 1481.56 & 549.11 & 304.40 & 324.16 & 6.45 \\
\hline Ekstreme 1 & 1521.74 & 512.05 & 4879.59 & 206.20 & 855.75 \\
\hline Daya Layan 1 & 1230.06 & 443.45 & 232.69 & 259.33 & 5.48 \\
\hline
\end{tabular}

Sesuai kontrol pada abutment dan pilar serta kontrol tiang pancang sesuai kondisi tanah didapatkan dimensi abutment 11.1 x $2.1 \times 7.3$ meter dan pilar 11.4 × 2.1 x 1.4 meter serta tiang pancang dari PT Wijaya Karya untuk abutment sebanyak 21 buah dan untuk pilar sebanyak 60 buah dengan diameter tiang pancang sebesar $1000 \mathrm{~mm}$ [14].

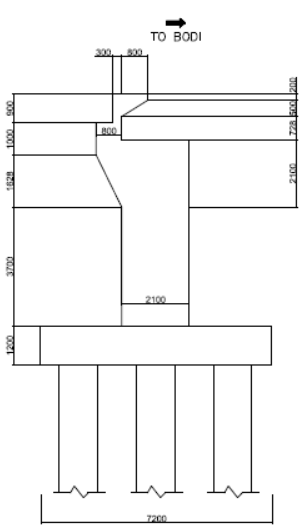

$\frac{\text { ABUTMENT A1 }}{\text { SCALE } 1: 200}$

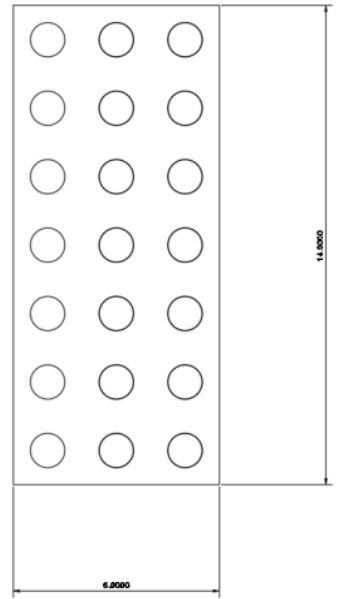

Gambar 11. Desain Abutment dan Konfigurasi Tiang Pancang

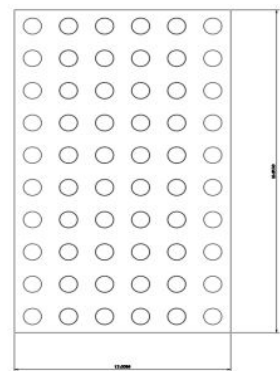

Gambar 12. Desain Pilar dan Konfigurasi Tiang Pancang

\section{KESIMPULAN}

1. Perancanaan pelat lantai kendaraan merupakan pelat beton yang memiliki ketebalan $20 \mathrm{~cm}$ dan dilapisi aspal dengan ketebalan $5 \mathrm{~cm}$.

2. Profil struktur sekunder Jembatan Buol menggunakan produk dari 3 sumber yaitu JFE Steel Coorporation untuk profil WF dengan mutu baja ASTM A36 (fu = $390 \mathrm{Mpa}$ dan fy $=250 \mathrm{Mpa}$ ), PT. Gunung Garuda untuk profil siku dengan mutu baja ASTM A36 (fu = $390 \mathrm{Mpa}$ dan fy $=250 \mathrm{Mpa}$ ) dan Steel Tube Institute of North America untuk profil Circullar hollow dengan mutu ASTM A500 GrB (fu = $400 \mathrm{Mpa}$ dan fy $=290$ Mpa). Dari hasil perhitungan struktur sekunder jembatan busur didapatkan: 
- Gelagar memanjang WF 434 x 299 x 10 x 15

- Gelagar melintang WF 786 x 384 x 19.7 x 33.4

- Ikatan angin lantai kendaraan L 200 x 200 x 20

- Ikatan angin tepi atas O 8.625"

- Ikatan silang angin rangka O 7"

- Ikatan angin tepi bawah O 8.625"

3. Profil rangka utama menggunakan brosur Corus Tubes Structural \& Conveyance Business yang memiliki mutu SN490 B (fy = 345 Mpa dan fu = $490 \mathrm{Mpa}$ )

Berikut merupakan rekap profil rangka utama

Batang tepi atas segmen 1 - 2 Box 550 x 550 x 32

Batang tepi atas segmen $3 \& 5$ Box $350 \times 350 \times 19$

Batang tepi atas segmen 4 \& 6 Box $400 \times 400 \times 22$

Batang tepi bawah segmen 1 \& 6 Box 350 x 350 x 19

Batang tepi bawah segmen 2 Box $500 \times 500 \times 28$

Batang tepi bawah segmen $3 \& 4$ Box $650 \times 650 \times 36$

Batang tepi bawah segmen 5 Box $450 \times 450 \times 25$

Batang vertikal segment $1 \& 3$ Box 350 x 350 x 19

Batang vertikal segment 4 Box 450 x 450 × 25

Batang vertikal segment $5 \& 6$ Box $350 \times 350 \times 19$

Batang diagonal segmen 1 - 3 Box $350 \times 350 \times 19$

Batang diagonal segmen $4 \& 5$ Box $400 \times 400 \times 22$

Batang diagonal segmen 6 Box $350 \times 350 \times 19$

Batang tarik Box $500 \times 500 \times 28$

Kolom portal akhir Box $500 \times 500 \times 22$

Balok portal akhir Box $500 \times 500 \times 22$

Batang penggantung Full Locked Cables berdiameter $50 \mathrm{~mm}$ (fy = 734 Mpa dan fu = $1211.64 \mathrm{Mpa}$ )

4. Perletakaan yang digunakan mengguanakan POT Bearing dari perusahaan Freyssinet dengan tipe GG 30000, GG 20000, FX 30000 dan GL 4000

5. Abutment jembatan memiliki tinggi 7.3 meter dan panjang 11.1 meter dengan lebar poer 6 meter, panjang 14 meter dan tebal 1.2 meter. Mutu beton yang digunakan adalah f'c 29 Mpa dan mutu tulangan adalah fy $392 \mathrm{MPa}$.

6. Pilar jembatan memiliki tinggi 1.4 meter, lebar 2.1 dan panjang 11.4 meter dengan lebar poer 12 meter, panjang 20 meter tebal 1.5 meter. Mutu beton yang digunakan adalah f'c 29 Mpa dan mutu tulangan adalah fy $392 \mathrm{MPa}$.

7. Pondasi struktur menggunakan tiang pancang spun pile PT. WIKA BETON dengan diameter $100 \mathrm{~cm}$ Tipe C untuk abutment yang memiliki kedalaman 18 meter dan diameter $100 \mathrm{~cm}$ Tipe $\mathrm{C}$ untuk pilar yang memiliki kedalaman 15 meter sesuai dengan penyelidikan tanah SPT (Standard Penetration Test). Jumlah tiang pancang yang dibutuhkan untuk abutment sebanyak 21 buah dan untuk pilar sebanyak 60 buah

\section{UCAPAN TERIMA KASIH}

Penulis D.W mengucapkan terima kasih kepada PT. Brantas Abipraya (Persero) yang telah memberikan dukungan berupa data-data yang diperlukan pada tugas akhir ini.

\section{DAFTAR PUSTAKA}

[1] Badan Standarisasi Nasional, "SNI 2833:2008Standa Perencanaan Ketahanan Gempa untuk Jembatan," Jakarta, 2008.

[2] R. M. Barker and J. A. Puckett., Design of Highway Bridges: An LRFD Approach, 3rd ed. USA: John Wiley \& Sons Inc, 2013.

[3] Badan Standarisasi Nasional, "RSNI T-03-2005 Perencanaan Struktur Baja untuk Jembatan,” Jakarta, 2005.

[4] Badan Standardisasi Nasional, "Bridge Management System (BMS) Peraturan Perencanaan Teknik Jembatan,” Jakarta, 1992.

[5] G. P. Steen, "Design study of a three span continuous tied-arch bridge," 1993.

[6] Badan Standarisasi Nasional, "SNI 1725:2016 Pembebanan untuk Jembatan," Jakarta, 2016.

[7] JFE Steel Corporation, "Wide Flange Shapes," Japan, 2011.

[8] G. Garuda, “Angle (Hot Rolled)," Bekasi, 2016.

[9] Steel Tube Institute, "Hollow Structural Section Dimensions and Section Properties," USA, 2002.

[10] Corus UK Limited, "Jumbo Structural Hollow Section," United Kingdom, 2003.

[11] Soletanche Freyssinet, "Freyssinet Mechanical Bearings," France, 2016.

[12] American Institute of Steel Construction, "ANSI/AISC 360-10 Specification for Structural Steel Buildings," USA, 2010.

[13] W. Chen and J. Y. R. Liew, The Civil Engineering Handbook Second Edition. USA: CRC Press LLC, 2002.

[14] PT. Wijaya Karya Beton, "Brochure The Precast Concrete Manufacturer,” Bekasi, 2017. 